\title{
Inhibitory Effect of Dimethyl Sulfoxide (DMSO) on Necrosis and Oxidative Stress Caused by D-Galactosamine in the Rat Liver
}

\author{
Chinatsu IIDA, Kozue FujII, Eriko Koga, Yukiko Washino, Ikuyo ICHI and Shosuke Kojo* \\ Department of Food Science and Nutrition, Nara Women's University, Nara 630-8506, Japan \\ (Received September 22, 2006)
}

\begin{abstract}
Summary D-Galactosamine (D-Galn: $300 \mathrm{mg} / \mathrm{kg}$ ) was intraperitoneally administered to rats. After $6 \mathrm{~h}$ the activity of plasma GOT and GPT was significantly higher than that of the control group and plasma GOT and GPT activities increased thereafter. These results indicated that the necrotic process was initiated at about $6 \mathrm{~h}$ and developed thereafter. With coadministration of DMSO ( $1 \mathrm{~h}$ before administration of D-Galn: $2.5 \mathrm{~mL} / \mathrm{kg}$, oral), plasma GOT and GPT were significantly lower, showing that DMSO inhibited the necrotic action of DGaln. After 6-24 h of D-Galn administration, the hepatic level of vitamin C, the most sensitive indicator of oxidative stress, decreased significantly, indicating that oxidative stress was significantly enhanced $6 \mathrm{~h}$ after D-Galn intoxication and thereafter. DMSO significantly restored the liver vitamin $\mathrm{C}$ level $24 \mathrm{~h}$ after D-Galn injection, demonstrating that DMSO effectively ameliorated the oxidative stress caused by D-Galn, resulting in the prevention of necrosis of the liver. Phosphorylated JNK and phospho-ERK were significantly increased transiently 6-12 h after treatment with D-Galn. These results indicated that oxidative stress and the activation of JNK took place almost simultaneously. Phosphorylated p38 MAPK was not changed and DMSO treatment did not affect the change of these MAPKs by D-Galn.
\end{abstract}

Key Words DMSO, galactosamine, MAPK, oxidative stress, vitamin C

Hepatoprotection remains one of the major challenges in nutritional and clinical therapy to limit liver injuries such as chronic hepatitis and fulminant hepatic failure. To study this issue more effectively, experimental methods are necessary to cause effective hepatic failure. Chemical toxins such as D-galactosamine (D-Galn) (1), thioacetamide (2), and carbon tetrachloride (3) have been used for this purpose. D-Galn is known as a toxin causing necrosis of the liver by UTP depletion and inhibition of protein synthesis (4). Recently, we reported that radical reactions were caused by D-Galn in the early stage based on a decrease in vitamin C (1), resulting in necrosis. In chemically induced hepatitis (1-3), liver vitamin $\mathrm{C}$ was firstly consumed by oxidative stress, indicating that vitamin $\mathrm{C}$ was the most sensitive indicator of oxidative stress (5).

Antioxidants in foods are therefore expected to protect the liver from oxidative stress caused by these chemicals. To survey the antioxidative effect of food factors, it is necessary to investigate effects of a known antioxidant on the liver. Only limited studies are available and DMSO is reported to function as an antioxidant in cultured hepatocytes (6) as well as in the rat liver under thioacetamide intoxication $(6-8)$. In this

\footnotetext{
*To whom correspondence should be addressed.

E-mail: kojo@cc.nara-wu.ac.jp

Abbreviations: D-Galn, D-galactosamine; DMSO, dimethyl sulfoxide; ERK, extracellular signal-regulated kinase; GOT, glutamate-oxaloacetate transaminase; GPT, glutamate-pyruvate transaminase; JNK, c-Jun $\mathrm{NH}_{2}$-terminal kinase; MAPK, mitogen activated protein kinase.
}

report, we have attempted to investigate whether DMSO functions in vivo as an antioxidant and protects against necrosis of the liver caused by D-Galn even in a pharmacological dose. For this purpose we evaluated oxidative stress using hepatic vitamin $\mathrm{C}$ level and activation profiles of the three major subclasses of the MAPK (mitogen activated protein kinase) family, namely, JNK (c-Jun $\mathrm{NH}_{2}$-terminal kinase), p38 MAPK, and ERK (extracellular signal-related kinase), which were activated by a high dose of D-Galn intoxication (9).

\section{MATERIALS AND METHODS}

Animals. This study was approved by the Animal Care Committee of Nara Women's University. Male rats (SLC: Wistar strain) were obtained from Japan SLC Co. (Hamamatsu, Shizuoka, Japan). The animals were housed in a room at $24 \pm 2^{\circ} \mathrm{C}$ with a $12 \mathrm{~h} / 12 \mathrm{~h}$ lightdark cycle. Animals were fed commercial laboratory chow (MF, Oriental Yeast Co., Osaka, Japan) and water ad libitum. Eight-week-old rats were used.

Design of this study. To evaluate the effect of DMSO on D-Galn toxicity, 4 groups were prepared. One hour before intraperitoneal administration of D-Galn (300 $\mathrm{mg} / \mathrm{kg}$ as a $0.3 \mathrm{~mL}$ saline solution), the DMSO group orally received DMSO $(2.5 \mathrm{~mL} / \mathrm{kg})$. For comparison, the D-Galn group received water $(2.5 \mathrm{~mL} / \mathrm{kg})$ instead of DMSO. Six, 12, and $24 \mathrm{~h}$ after D-Galn injection, determinations were made. Control rats received intraperitoneally $0.3 \mathrm{~mL}$ of saline instead of D-Galn and determinations were made after $6 \mathrm{~h}$. The sham group orally received DMSO $(2.5 \mathrm{~mL} / \mathrm{kg})$ as in the DMSO group and 
determinations were made after $7 \mathrm{~h}$.

Analytical methods. Rats were anesthetized with diethyl ether and killed by collecting the blood from the inferior vena cava using a syringe containing sodium heparin as an anticoagulant. After perfusion of icecooled saline through the portal vein, organs were removed. The excised tissue was homogenized in 5 volumes of phosphate buffered saline (10 mM, pH 7.4) under ice cooling. All determinations were made in duplicate experiments with 4-7 animals in each group. The determination of vitamin $\mathrm{C}$ was made according to a specific and sensitive method $(1,10)$ involving chemical derivatization and HPLC. The concentration of $\alpha$ tocopherol was determined by HPLC (1). The conditions of HPLC and fluorescence detection (Shimadzu RF-535, Kyoto, Japan) were reported previously (11). Blood was centrifuged at $8,400 \times g$ for $5 \mathrm{~min}$ at $4^{\circ} \mathrm{C}$ to separate plasma. The activities of plasma glutamate-oxaloacetate transaminase (GOT: EC 2.6.1.1) and glutamate-pyruvate transaminase (GPT: EC 2.6.1.2) were determined using diagnostic kits (GOT and GPT-UV Test Wako, Wako Pure Chemicals Co., Osaka) and expressed as Karmen units.

Western blot analysis of JNK, ERK, and p38 MAPK. Liver tissue was removed and frozen at $-83^{\circ} \mathrm{C}$ until use.
Determination was made as previously described (9). Homogenization was done basically as reported (12). The extraction buffer contained $10 \mathrm{~mm}$ Tris- $\mathrm{HCl}(\mathrm{pH}$ 7.5), $0.25 \mathrm{~m}$ sucrose, $5 \mathrm{~mm}$ EDTA, $50 \mathrm{~mm}$ sodium chloride, $30 \mathrm{~mm}$ sodium pyrophosphate, $50 \mathrm{~mm}$ sodium fluoride, $100 \mu \mathrm{M}$ of sodium orthovanadate, $1 \mu \mathrm{g} / \mathrm{mL}$ of pepstatin A, $2 \mu \mathrm{g} / \mathrm{mL}$ of leupeptin, and $1 \mathrm{~mm}$ of phenylmethylsulfonyl fluoride (PMSF). Samples were homogenized in five volumes of the extraction buffer on ice. All debris and nuclei were removed by centrifugation at $8,400 \times \mathrm{g}$ at $4^{\circ} \mathrm{C}$ for $10 \mathrm{~min}$, and the supernatant obtained was used for Western blot analysis. Protein concentrations were determined according to the method of Lowry et al. (13) using BSA as the standard. One hundred micrograms of protein were electrophoresed on a $10 \%$ SDS-PAGE gel, and transferred to BioTrace NT membranes (Pall Gelman Laboratory, Ann Arbor, MI, USA).

Detection of phosphorylated p38 MAPK, JNK, and ERK was done according to the instruction manual provided by Cell Signaling Technology Inc. (Beverly, MA, USA) using a PhosphoPlus p38 MAP Kinase (Thr180/ Tyr182) Antibody Kit, a PhosphoPlus SAPK/JNK (Thr183/Tyr185) Antibody Kit, and a PhosphoPlus p44/42 MAP Kinase (Thr202/Tyr204) Antibody Kit,

Table 1. Change in plasma GOT and GPT and liver concentrations of vitamins C and E.

\begin{tabular}{|c|c|c|c|c|}
\hline & \multirow{2}{*}{ Control } & \multirow{2}{*}{ Sham } & \multicolumn{2}{|c|}{$6 \mathrm{~h}$} \\
\hline & & & D-Galn & DMSO \\
\hline $\begin{array}{l}\text { GOT } \\
\text { (Karmen units) }\end{array}$ & $\begin{array}{c}65.1 \pm 8.1 \\
\quad(n=4)\end{array}$ & $\begin{array}{l}68.7 \pm 25.5 \\
\quad(n=4)\end{array}$ & $\begin{array}{c}470.9 \pm 202.5^{*} \\
(n=7)\end{array}$ & $\begin{array}{c}530.5 \pm 64.5^{*} \\
(n=5)\end{array}$ \\
\hline $\begin{array}{l}\text { GPT } \\
\quad \text { (Karmen units) }\end{array}$ & $\begin{array}{c}27.2 \pm 3.9 \\
(n=4)\end{array}$ & $\begin{array}{c}22.1 \pm 7.4 \\
(n=4)\end{array}$ & $\begin{array}{c}224.1 \pm 82.6^{*} \\
\quad(n=7)\end{array}$ & $\begin{array}{c}204.6 \pm 71.4^{*} \\
(n=5)\end{array}$ \\
\hline $\begin{array}{l}\text { Vitamin C } \\
\quad(\mathrm{nmol} / \mathrm{g} \text { liver })\end{array}$ & $\begin{array}{c}2,052.0 \pm 183.1 \\
(n=4)\end{array}$ & $\begin{array}{c}2,031.8 \pm 236.6 \\
(n=4)\end{array}$ & $\begin{array}{c}1,397.2 \pm 232.2^{*} \\
(n=7)\end{array}$ & $\begin{array}{c}1,566.7 \pm 227.2^{*} \\
(n=5)\end{array}$ \\
\hline \multirow[t]{3}{*}{$\begin{array}{l}\text { Vitamin } \mathrm{E} \\
\text { (nmol/g liver) }\end{array}$} & $\begin{array}{c}18.4 \pm 1.9 \\
(n=4)\end{array}$ & $\begin{array}{l}18.8 \pm 5.3 \\
\quad(n=4)\end{array}$ & $\begin{array}{l}28.8 \pm 6.8^{*} \\
\quad(n=7)\end{array}$ & $\begin{array}{l}30.1 \pm 3.2^{*} \\
\quad(n=5)\end{array}$ \\
\hline & \multicolumn{2}{|c|}{$12 \mathrm{~h}$} & \multicolumn{2}{|c|}{$24 \mathrm{~h}$} \\
\hline & D-Galn & DMSO & D-Galn & DMSO \\
\hline $\begin{array}{l}\text { GOT } \\
\text { (Karmen units) }\end{array}$ & $\begin{array}{c}2,623.9 \pm 603.9^{*, * *} \\
(n=4)\end{array}$ & $\begin{array}{l}778.0 \pm 142.3^{*} \\
\quad(n=4)\end{array}$ & $\begin{array}{c}8,348.1 \pm 1,717.8^{*, * *} \\
(n=4)\end{array}$ & $\begin{array}{c}3,438.0 \pm 935.2^{*} \\
(n=4)\end{array}$ \\
\hline $\begin{array}{l}\text { GPT } \\
\text { (Karmen units) }\end{array}$ & $\begin{array}{l}975.0 \pm 240.5^{*, * *} \\
\quad(n=4)\end{array}$ & $\begin{array}{c}272.6 \pm 70.2^{*} \\
\quad(n=4)\end{array}$ & $\begin{array}{c}4,048.8 \pm 906.4^{*, * *} \\
(n=4)\end{array}$ & $\begin{array}{c}1,833.3 \pm 438.7^{*} \\
(n=4)\end{array}$ \\
\hline $\begin{array}{l}\text { Vitamin C } \\
\text { (nmol/g liver) }\end{array}$ & $\begin{array}{c}1,254.3 \pm 41.1^{*} \\
(n=4)\end{array}$ & $\begin{array}{c}1,352.5 \pm 64.9^{*} \\
(n=4)\end{array}$ & $\begin{array}{l}904.2 \pm 183.5^{*, * *} \\
(n=4)\end{array}$ & $\begin{array}{c}1,216.1 \pm 113.1^{*} \\
(n=4)\end{array}$ \\
\hline $\begin{array}{l}\text { Vitamin E } \\
\quad \text { (nmol/g liver) }\end{array}$ & $\begin{array}{l}25.0 \pm 1.2^{*} \\
\quad(n=4)\end{array}$ & $\begin{array}{l}29.6 \pm 5.6^{*} \\
(n=4)\end{array}$ & $\begin{array}{l}32.9 \pm 5.8^{*} \\
(n=4)\end{array}$ & $\begin{array}{l}33.0 \pm 11.7^{*} \\
\quad(n=4)\end{array}$ \\
\hline
\end{tabular}

D-Galn $(300 \mathrm{mg} / \mathrm{kg})$ was administered to rats. One hour before administration of D-Galn, the D-Galn group received $\mathrm{H}_{2} \mathrm{O}$ $(2.5 \mathrm{~mL} / \mathrm{kg})$ and the DMSO group received DMSO $(2.5 \mathrm{~mL} / \mathrm{kg})$. After 6,12 , and $24 \mathrm{~h}$, plasma GOT and GPT, and the liver concentration of vitamins $\mathrm{C}$ and $\mathrm{E}$ were determined as described in the text. Control rats received saline and determinations were made after $6 \mathrm{~h}$. The sham group received DMSO $(2.5 \mathrm{~mL} / \mathrm{kg})$ and determinations were made after $7 \mathrm{~h}$. Values are means \pm SD. The number of rats is shown in paretheses. Single asterisks $\left(^{*}\right)$ indicate significant differences from the control group and double asterisks $\left({ }^{* *}\right)$ indicate significant differences from the DMSO group (ANOVA Fisher's protected least significant difference test (PLSD)). 
(A)

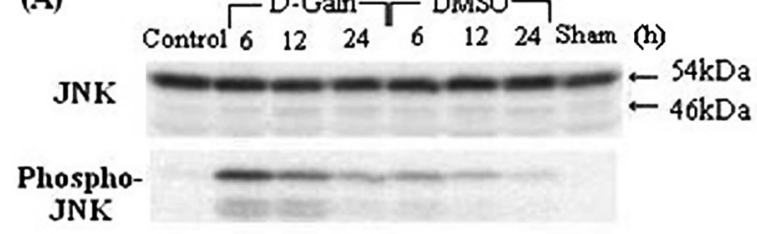

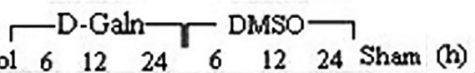
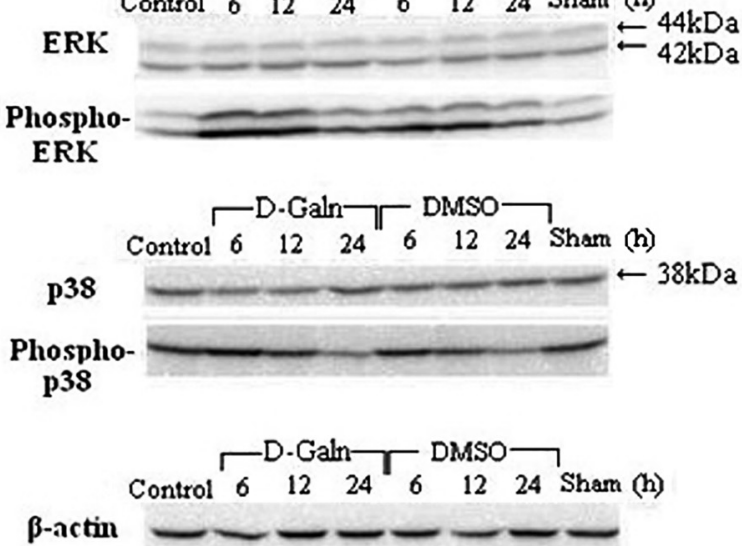

(B)
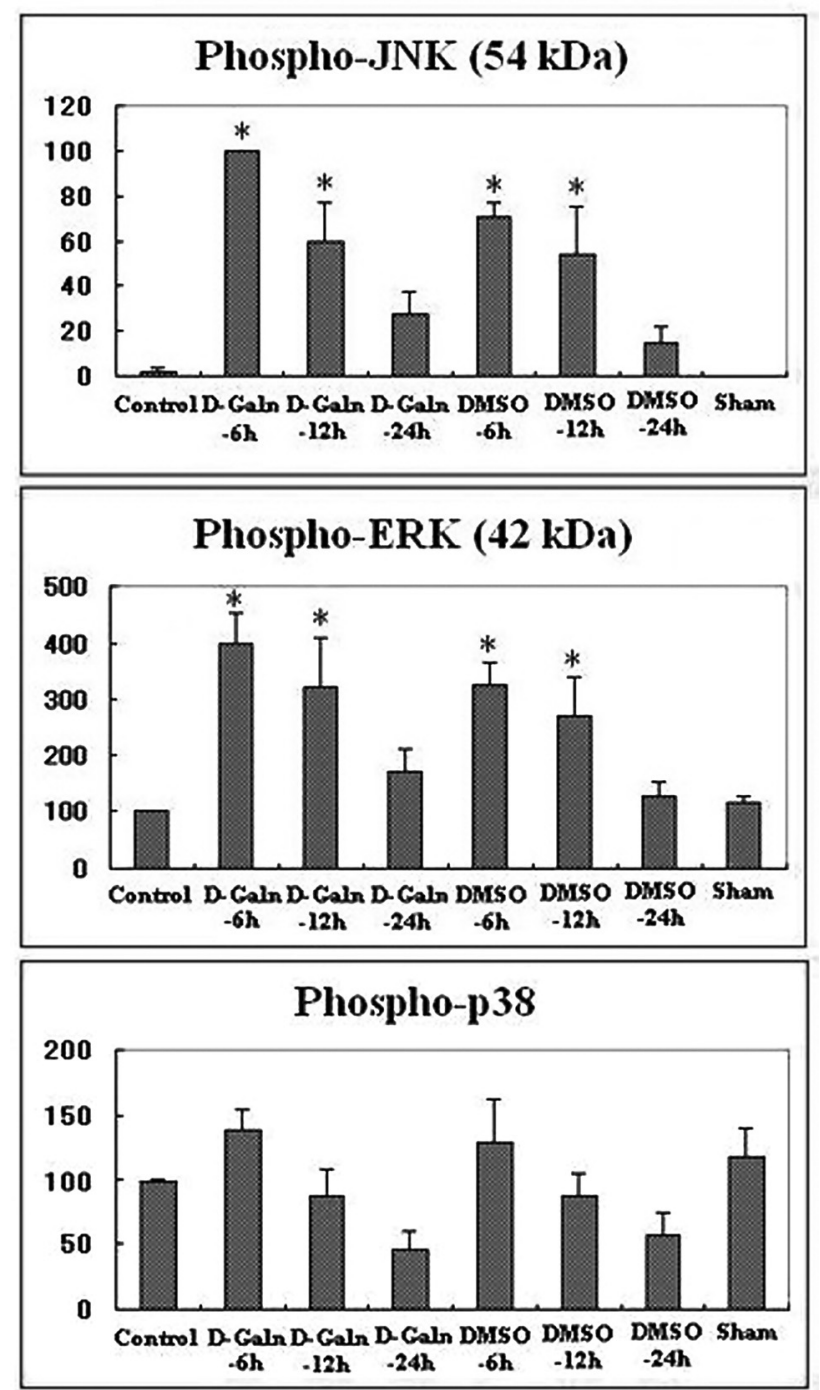

respectively. These kits were purchased from Cell Signaling Technology Inc. (Beverly, MA, USA).

Chemiluminescence was recorded with a cooled CCD camera system (Type AE-6972, ATTO Co. Ltd., Tokyo, Japan) and analyzed with ATTO Densitograph Software Library, CS Analyzer Ver2.0).

Data were expressed as mean \pm SD. Statistical analysis was carried out with Statcel (Excel 2000). Differences between the group means were considered significant at $p<0.05$ using Fisher's protected least significant difference test (PLSD), following detection of an effect by one-way ANOVA.

\section{RESULTS}

Liver necrosis caused by D-Galn and its inhibition by DMSO

D-Galn $(300 \mathrm{mg} / \mathrm{kg})$ was administered to rats. After $6 \mathrm{~h}$, the activities of plasma GOT and GPT in the D-Galn group were significantly higher than those of the control group (Table 1). After 12 and $24 \mathrm{~h}$, plasma GOT and GPT activities increased drastically compared to the control group. These results indicated that the necrotic process was initiated at about $6 \mathrm{~h}$ and developed extensively thereafter.

Plasma GOT and GPT were significantly lower in the DMSO group compared to the D-Galn group 12 and $24 \mathrm{~h}$ after D-Galn administration (Table 1). Plasma GOT and GPT of the control were almost identical with those of the sham group, showing that DMSO did not affect the normal liver. These results demonstrated that DMSO significantly inhibited the necrotic action of D-Galn.

Effect of DMSO on the levels of vitamins $C$ and $E$ in rats treated with D-Galn

In a previous study (1), we demonstrated that D-Galn caused apoptosis and necrosis by oxidative stress, which was indicated most sensitively by a decrease in liver vitamin C (5). Therefore, determinations of antioxidative vitamins $\mathrm{C}$ and $\mathrm{E}$ were made. Six hours after D-Galn administration, the hepatic level of vitamin $\mathrm{C}$ decreased significantly and fell thereafter (Table 1). After $24 \mathrm{~h}$, vitamin $\mathrm{C}$ in the liver decreased drastically to less than a half of the control liver level (Table 1). Although vita-

Fig. 1. MAPK and phospho-MAPK in the livers of rats 6,12 , and $24 \mathrm{~h}$ after D-Galn injections (D-Galn and DMSO groups), the control group, and the sham group. One hour before administration of D-Galn, the D-Galn group received $\mathrm{H}_{2} \mathrm{O}(2.5 \mathrm{~mL} / \mathrm{kg})$ and the DMSO group received DMSO $(2.5 \mathrm{~mL} / \mathrm{kg})$. After 6,12 , and $24 \mathrm{~h}$, protein concentrations of MAPK and phosphorylated MAPK (described as phospho-JNK, phospho-ERK, and phospho-p38) in the livers were determined as described in the text. Control rats received saline and determinations were made after $6 \mathrm{~h}$. The sham group received DMSO $(2.5 \mathrm{~mL} / \mathrm{kg})$ and determinations were made after $7 \mathrm{~h}$. In (A), a typical result of blotted membranes is shown and in the lower panel (B), densitometry of phospho-MAPK is shown. Values are means \pm SE of 4 rats. Single asterisks $\left(^{*}\right)$ indicate significant differences from the control group (ANOVA Fisher's protected least significant difference test (PLSD)). 
min $\mathrm{C}$ is not essential for Wistar rats, oxidative stress caused by D-Galn led to a depletion of vitamin C. These results demonstrated that oxidative stress was significantly enhanced $6 \mathrm{~h}$ after D-Galn intoxication and progressed thereafter.

By co-administration of DMSO, the liver vitamin C was lower compared to the control group but significantly higher than that in the D-Galn group only $24 \mathrm{~h}$ after D-Galn injection (Table 1). This result indicated that DMSO effectively attenuated the oxidative stress caused by D-Galn at a later stage when extensive necrosis took place. The vitamin E concentration in the liver was increased by D-Galn intoxication, consistent with the previous study (1). DMSO did not affect the change in liver vitamin E concentration (Table 1). The liver concentrations of vitamins $\mathrm{C}$ and $\mathrm{E}$ in the sham group were not different from those in the control group, indicating that DMSO did not influence these vitamins in the normal liver.

Effect of DMSO on MAPK in rats treated with D-Galn

Phosphorylated JNK at $54 \mathrm{kDa}$ significantly increased transiently 6-12 h after treatment with DGaln, when the oxidative stress had significantly increased as evidenced by decreased liver vitamin $\mathrm{C}$ and liver necrosis was evident based on plasma GOT and GPT levels (Table 1), while the JNK protein level was almost the same as that of the control from 6 to $24 \mathrm{~h}$ after D-Galn treatment (Fig. 1). Phospho-JNK protein was scarcely detected in the control and sham groups (Fig. 1).

Phosphorylated ERK at $42 \mathrm{kDa}$ was significantly increased 6-12 $\mathrm{h}$ after D-Galn injection, while the level of ERK1 and ERK2 proteins was almost the same as that in the control and the sham groups from 6 to $24 \mathrm{~h}$ after D-Galn treatment (Fig. 1). These results indicated that the activation of ERK took place simultaneously with an elevation of oxidative stress as evaluated by the vitamin C level.

Phosphorylated p38 MAPK was not changed from 6 to $24 \mathrm{~h}$ after D-Galn treatment (Fig. 1).

Co-administration of DMSO did not affect activation profiles of these MAPKs (Fig. 1).

\section{DISCUSSION}

DMSO effectively inhibited necrosis caused by D-Galn based on plasma GOT and GPT. Although D-Galn is a well-established hepatotoxin causing typical necrosis, we reported that D-Galn at a dose of $1 \mathrm{~g} / \mathrm{kg}$ body weight caused severe necrosis involving oxidative stress on the basis of the decrease in vitamin $\mathrm{C}$ and increase in lipid hydroperoxides (1). However DMSO did not inhibit liver necrosis at a dose of $1 \mathrm{~g} / \mathrm{kg}$ (data not shown). Therefore a lower dose $(300 \mathrm{mg} / \mathrm{kg}$ ) was used in this study where the effect of DMSO was observed clearly and oxidative stress and MAPK activation were examined at the present dose.

In a series of papers $(1-3,5)$, we demonstrated that the concentration of vitamin $\mathrm{C}$, abundant and the strongest antioxidant in animal tissues, reflected oxidative stress most sensitively in the rat liver during chemi- cal intoxication. The hepatic level of vitamin $\mathrm{C}$ decreased significantly $6 \mathrm{~h}$ after D-Galn administration and decreased further thereafter (Table 1), showing that oxidative stress was significantly enhanced $6 \mathrm{~h}$ after D-Galn intoxication at a dose of $300 \mathrm{mg} / \mathrm{kg}$. It may be argued that the decrease in vitamin $C$ is due to the liver damage i.e., inhibition of vitamin $\mathrm{C}$ synthesis, and not due to the oxidative stress. However we reported that vitamin $\mathrm{C}$ deficiency in ODS rats (inherently scorbutic rats) for $24 \mathrm{~h}$ caused only $15-20 \%$ decrease in the liver vitamin $C$ (14). Therefore the decrease in vitamin $\mathrm{C}$ by $55 \%$ during $24 \mathrm{~h}$ is mainly due to the oxidative stress caused by D-Galn.

By co-administration of DMSO, the decrease in liver vitamin $\mathrm{C}$ was attenuated (Table 1 ). This result indicated that DMSO inhibited the oxidative stress caused by D-Galn and functioned as an antioxidant, resulting in the decrease in necrosis of the liver cells $24 \mathrm{~h}$ after DGaln injection when necrosis was maximal. The liver concentration of vitamin $\mathrm{E}$ was increased by D-Galn intoxication as in our previous study (1). The mechanism of this increase in vitamin E remained unexplored. It was possible that some mechanism mobilizing vitamin E to a tissue where oxidative stress was enhanced operated.

Oxidative stress causes many events in cells and MAPKs have received much attention as a target of reactive oxygen species. The proteins comprising the MAPK family are important mediators of signal transduction processes that serve to regulate diverse cellular responses to extracellular stimuli. The three major subclasses of the MAPK family are JNK, ERK, and p38 MAPK. Among them, JNK was activated in the induction of hepatocyte death by thioacetamide (6), TGF- $\beta 1$ $(15,16)$, ischemia-reperfusion (12), menadione (17), carbon tetrachloride (18), and D-Galn (10).

Phosphorylated JNK at $54 \mathrm{kDa}$ and phospho-ERK significantly increased transiently 6-12 h after treatment with D-Galn, when the liver vitamin $\mathrm{C}$ decreased as in a previous study (9). These results indicated that oxidative stress and the activation of JNK and ERK took place almost simultaneously, as previously reported (9). This result also indicated that oxidative stress and the activation of these MAPKs took place without delay if the former caused the latter as generally assumed.

Although it is still controversial, ERK has been reported to be cytoprotective against apoptosis triggered by oxidative stress $(17,19,20)$, tumor necrosis factor $\alpha$ $(21,22)$ growth factor deprivation $(23)$, and proapoptotic drugs (24), in contrast to JNK. In addition, hepatocyte resistance to oxidative stress depends on protein kinase $\mathrm{C}$ and ERK-mediated down regulation of JNK signaling (17). In the present study, phospho-ERK2 was clearly augmented 6-12 h after the D-Galn injection (Fig. 1). However, extensive necrosis took place $6 \mathrm{~h}$ after D-Galn administration. These findings implied that the activation of ERK took place, and that the strong apoptotic and necrotic signal induced by a high dose of DGaln could block cell responses to growth and survival factors acting through the ERK pathway. 
DMSO treatment did not significantly affect the change in these MAPKs induced by D-Galn in spite of significant changes in plasma GOT and GPT as well as liver vitamin C. It is possible that DMSO inhibited the liver necrosis without affecting MAPKs. On the other hand many studies demonstrate that oxidative stress causes MAPK activation. It may be difficult to detect a small change by Western blot and densitometric analysis because of its large SD in nature in contrast to chemical analysis such as vitamin C, GOT, and GPT.

Phosphorylated p38 MAPK was not significantly changed by administration of D-Galn $(300 \mathrm{mg} / \mathrm{kg}$, this study), while it was increased by D-Galn at a dose of $1 \mathrm{~g}$ / kg (9), where DMSO did not show an appreciable protective effect (data not shown). This may be due to the decrease in the dose of D-Galn.

Under oxidative stress not only MAPK but also other signals such as NF-KB (25) and MAPK phosphatases (26) are activated. Involvement of these factors in the hepatitis caused by D-Galn must be examined in future.

In conclusion, D-Galn caused severe necrosis of the liver by oxidative stress involving changes in MAPKs such as JNK, ERK, and p38 MAPK. Co-treatment of rats with DMSO effectively inhibited the liver necrosis by attenuating the oxidative stress.

\section{REFERENCES}

1) Sun F, Hamagawa E, Tsutsui C, Sakaguchi N, Kakuta Y, Tokumaru S, Kojo S. 2003. Evaluation of oxidative stress during apoptosis and necrosis caused by D-galactosamine in rat liver. Biochem Pharmacol 65: 101-107.

2) Sun F, Hayami S, Ogiri Y, Haruna S, Tanaka K, Yamada Y, Tokumaru S, Kojo S. 2000. Evaluation of oxidative stress based on lipid hydroperoxide, vitamin $\mathrm{C}$ and vitamin E during apoptosis and necrosis caused by thioacetamide in rat liver. Biochim Biophys Acta 1500: 181185.

3) Sun F, Tsutsui C, Hamagawa E, Ono Y, Ogiri Y, Kojo S. 2001. Evaluation of oxidative stress during apoptosis and necrosis caused by carbon tetrachloride in rat liver. Biochim Biophys Acta 1535: 186-191.

4) Plaa GL. 1991. Toxic response of the liver. In: Casarett and Doull's Toxicology (Amdur MO, Doull J, Klaassen CD, eds), 4th ed, p 334-353. Pergamon Press, New York.

5) Kojo S. 2004. Vitamin C, basic metabolism and its function as an index of oxidative stress. Curr Med Chem 11: 1041-1064.

6) Gilot D, Loyer P, Corlu A, Glaise D, Lagadic-Gossmann D, Atfi A, Morel F, Ichijo H, Guguen-Guillouzo C. 2002. Liver protection from apoptosis requires both blockage of initiator caspase activities and inhibition of ASK1/ JNK pathway via glutathione $S$-transferase regulation. $J$ Biol Chem 277: 49220-49229.

7) Bruck R, Aeed H, Shirin H, Matas Z, Zaidel L, Avni Y, Halper Z. 1999. The hydroxyl radical scavengers dimethylsulfoxide and dimethylthiourea protect rats against thioacetamide-induced fulminant hepatic failure. $J$ Hepatol 31: 27-38.

8) Tunez I, Munoz C, Villavicencio A, Medina FJ, de Prado EP, Espejo I, Barcos M, Salcedo M, Feijoo M, Montilla P. 2005. Hepato- and neurotoxicity induced by thioacetamide: protective effects of melatonin and dimethylsul- foxide. Pharmacol Res 52: 223-228.

9) Nishioka H, Kishioka T, Iida C, Fujii K, Ichi I, Kojo S. 2006. Activation of mitogen activated protein kinase (MAPK) during D-galactosamine intoxication in the rat liver. Bioorg Med Chem Lett 16: 3019-3022.

10) Kishida E, Nishimoto Y, Kojo S. 1992. Specific determination of ascorbic acid with chemical derivatization and high-performance liquid chromatography. Anal Chem 64: 1505-1507.

11) Kishida E, Kamura A, Tokumaru S, Oribe M, Iguchi H, Kojo S. 1993. Re-evaluation of malondialdehyde and thiobarbituric acid-reactive substances as indices of autoxidation based on the oxygen consumption. J Agric Food Chem 41: 1-4.

12) Kobayashi M, Takeyoshi I, Yoshinari D, Matsumoto K, Morishita Y. 2002. P38 mitogen-activated protein kinase inhibition attenuates ischemia-reperfusion injury of the rat liver. Surgery 131: 344-349.

13) Lowry OH, Rosebrough NJ, Farr AL, Randall J. 1951. Protein measurement with Folin phenol reagent. J Biol Chem 19: 265-275.

14) Tokumaru S, Takeshita S, Nakata R, Tsukamoto I, Kojo S. 1996. Change in the level of vitamin $\mathrm{C}$ and lipid peroxidation in tissues of the inherently scorbutic rat during ascorbate deficiency. J Agric Food Chem 44: 27482753.

15) Kim K-Y, Kim B-C, Xu Z, Kim S-J. 2004. Mixed lineage kinase 3 (MLK3)-activated p38 MAP kinase mediates transforming growth factor- $\beta$-induced apoptosis in hepatoma cells. J Biol Chem 279: 29478-29484.

16) Park H-J, Kim B-C, Kim S-J, Choi KS. 2002. Role of MAP kinases and their cross-talk in TGF- $\beta 1$-induced apoptosis in FaO rat hepatoma cell line. Hepatology 35: 13601371.

17) Wang Y, Schattenberg JM, Rigoli RM, Storz P, Czaja MJ. 2004. Hepatocyte resistance to oxidative stress is dependent on protein kinase C-mediated down-regulation of c-Jun/AP-1. J Biol Chem 279: 31089-31097.

18) Mendelson KG, Contois L-R, Tevosian SG, Davis RJ, Paulson KE. 1996. Independent regulation of JNK/p38 mitogen-activated protein kinases by metabolic oxidative stress in the liver. Proc Natl Acad Sci USA 93: 12908-12913.

19) Czaja MJ, Liu H, Wang Y. 2003. Oxidant-induced hepatocyte injury from menadione is regulated by ERK and AP-1 signaling. Hepatology 37: 1405-1413.

20) Tommasini I, Cerioni L, Guidarelli A, Cantoni O. 2005. ERK1/2-dependent regulation of U937 cell survival after exposure to peroxynitrite. Biochem Biophys Res Commun 329: 1282-1287.

21) Xia Z, Dickens M, Raingeaud J, Davis RJ, Greenberg ME. 1995. Opposing effects of ERK and JNK-p38 MAP kinases on apoptosis. Science 270: 1326-1331.

22) Gardner AM, Johnson GJ. 1996. Fibroblast growth factor-2 suppression of tumor necrosis factor $\alpha$-mediated apoptosis requires Ras and the activation of mitogenactivated protein kinase. J Biol Chem 271: 1456014566.

23) Tran SEF, Holmstroem TH, Ahonen M, Kaehaeri V-M, Eriksson JE. 2001. MAPK/ERK overrides the apoptotic signaling from Fas, TNF, and TRAIL receptors. J Biol Chem 276: 16484-16490.

24) Stadheim TA, Kucera GL. 1998. Extracellular signalregulated kinase (ERK) activity is required for TPAmediated inhibition of drug-induced apoptosis. Biochem 
Biophys Res Commun 245: 266-271.

25) Bauer I, Vollmar B, Jaeschke H, Rensing H, Kraemer T, Larsen R, Bauer M. 2000. Transcriptional activation of heme oxygenase- 1 and its functional significance in acetaminophen-induced hepatitis and hepatocellular injury in the rat. J Hepatol 33: 395-406.

26) Barr AJ, Knapp S. 2006. MAPK-specific tyrosine phosphatases: new targets for drug discovery? Trends Pharmacol Sci 27: 525-530. 